\title{
A new use for an old molecule: N-phenyl-2-(2-hydroxynaphthalen-1-ylmethylene)hydrazinecarbothioamide as a ratiometric 'Off-On' fluorescent probe for iron
}

\author{
María José Casanueva Marenco ${ }^{\mathrm{b}}$, Colin Fowley ${ }^{\mathrm{a}}$, Barry W. Hyland ${ }^{\mathrm{a}}$, Graham R.C. Hamilton ${ }^{\mathrm{a}}$, \\ Dolores Galindo-Riaño ${ }^{\mathrm{b}}$, John F. Callan ${ }^{\mathrm{a}, *}$ \\ ${ }^{a}$ Department of Pharmacy and Pharmaceutical Sciences, School of Biomedical Sciences, The University of Ulster, Northern Ireland BT52 1SA, United Kingdom \\ ${ }^{\mathrm{b}}$ Department of Analytical Chemistry, Faculty of Sciences, University of Cadiz, Campus Rıo S. Pedro, 11510 Puerto Real, Cadiz, Spain
}

\section{A R T I C L E I N F O}

\section{Article history:}

Received 27 October 2011

Revised 15 November 2011

Accepted 25 November 2011

Available online 2 December 2011

\section{Keywords:}

Fluorescence

Sensor

Iron(III)

Ratiometric

\begin{abstract}
A B S T R A C T
$N$-Phenyl-2-(2-hydroxynaphthalen-1-ylmethylene)hydrazinecarbothioamide has been investigated as a fluorescent sensor for the determination of $\mathrm{Fe}(\mathrm{III})$ in aqueous solutions. The probe was prepared by the facile Schiff base condensation of 2-hydroxy-1-napthaldehyde with $\mathrm{N}$-phenylhydrazinecarbothioamide. The sensor displayed good selectivity for $\mathrm{Fe}(\mathrm{III})$ when tested against a range of biologically and environmentally important cations. A concentration dependent increase in the emission of two fluorescent bands at 425 and $495 \mathrm{~nm}$ was observed upon increasing $\mathrm{Fe}(\mathrm{III})$ addition resulting in a linear ratiometric response in the 17-37 $\mu \mathrm{M}$ range. The binding stoichiometry was confirmed as 1:1 (host/guest) with the binding constant $(\log \beta)$ calculated as 4.56 .
\end{abstract}

(c) 2011 Elsevier Ltd. All rights reserved.
Iron is an essential element for normal physiological functioning as it plays an important role in many cellular processes including energy generation, oxygen transport and DNA synthesis. ${ }^{1}$ The ability of iron to redox cycle between two stable forms, $\mathrm{Fe}(\mathrm{II})$ and $\mathrm{Fe}(\mathrm{III})$, enables it to function as both an electron donor and acceptor, a property that makes it suitable as a co-factor in many different enzymes critical for life. ${ }^{2}$ However, iron overload can cause deleterious conditions such as $\beta$-thalassaemia and Friedreich's ataxia where the presence of excess iron leads to the generation of reactive oxygen species (ROS) via the Fenton reaction. ${ }^{3}$ ROS can induce cell death by interacting with many important biomolecules through a series of chemical reactions resulting in DNA oxidation, mitochondrial damage and lipid peroxidation. ${ }^{4}$ Iron is also essential for the catalytic activity of ribonucleotide reductase (RR), the enzyme used in the rate determining step of DNA synthesis. As cancer cells proliferate at a faster rate than normal cells, these cells tend to have a greater requirement for iron than healthy cells. ${ }^{5}$ Thus iron sequestration has also been a target in certain cancer chemotherapies. $^{3}$

To counter the problems of iron overload, iron chelation therapy utilises ligating drugs that strongly bind to intra- and extracellular iron promoting the excretion and subsequent depletion of toxic iron concentrations in the body. ${ }^{3}$ Currently, three drugs, deferi-

\footnotetext{
* Corresponding author. Tel.: +44 2870123059; fax: +44 2870123509.

E-mail address: j.callan@ulster.ac.uk (J.F. Callan).
}

prone, deferasirox and deferoxamine are approved for use in iron chelation therapy. ${ }^{6}$ However, in order to administer the optimum dose of these agents it would first be advantageous to determine the level of excess iron present. As a result, there is a need for the development of rapid detection systems that can determine the concentration of iron in aqueous based solutions. In this capacity, fluorescence based methods for analyte detection remain popular due to their high sensitivity, rapid response rate and relative inexpense. ${ }^{7}$

Thiosemicarbazones have been studied extensively as iron chelators in the treatment of cancer. Their high affinity for iron makes them ideal for sequestering iron at the active site of the RR enzyme thus inhibiting its function. ${ }^{8}$ A large family of thiosemicarbazone derivatives have been developed and investigated for their chemotherapeutic potential including those derived from 2-hydroxy-1naphthaldehyde. ${ }^{9}$ Given the high affinity these molecules have for $\mathrm{Fe}(\mathrm{III})$ and that they possess an inherent fluorophore within their structure, it seems sensible to investigate these compounds as potential fluorescent probes for iron. Surprisingly, to date, the ability of these agents to also function as self indicating fluorescent sensors for iron has been overlooked.

In this Letter, we synthesise the simplest member of this family, $\mathrm{N}$-phenyl-2-(2-hydroxynaphthalen-1-ylmethylene)hydrazinecarbothioamide (which in this Letter is designated NT) ${ }^{9}$ and investigate its ability to function as a fluorescent probe for $\mathrm{Fe}(\mathrm{III})$ in aqueous based solution. 
<smiles>NNC(=S)Nc1ccccc1</smiles><smiles>Oc1ccc2ccccc2c1/C=N\NC(=S)Nc1ccccc1</smiles>

Scheme 1. Synthesis of NT from 2-hydroxy-1-naphthaldehyde and 4-phenylthio-semicarbazide.

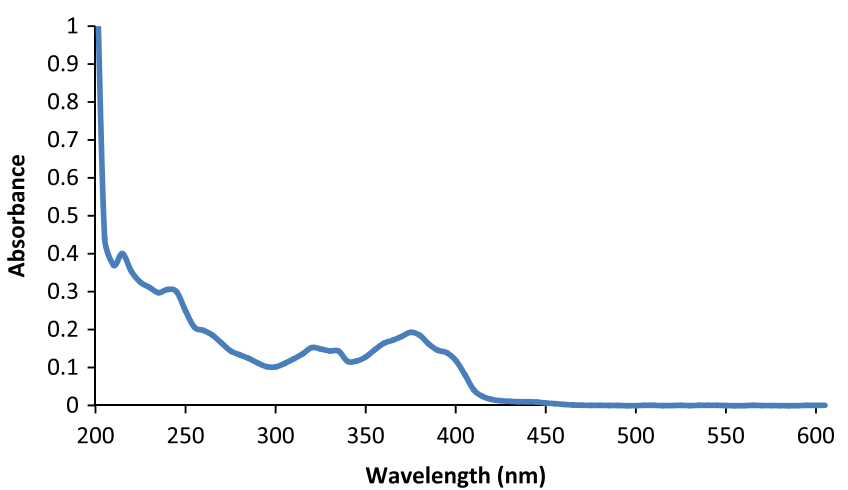

Figure 1. Absorbance spectrum of NT recorded in a $\mathrm{THF} / \mathrm{H}_{2} \mathrm{O}(9: 1)$ solvent system buffered at $\mathrm{pH}$ 7.4. [NT] $=10 \mu \mathrm{M}$.
The target compound NT was synthesised in one step by the facile Schiff base condensation reaction of 2-hydroxy-1-napthaldehyde with $\mathrm{N}$-phenylhydrazinecarbothioamide (4-phenylthiosemicarbazide) (Scheme 1) and was produced in a $65 \%$ yield after recrystallisation from ethanol. ${ }^{10}$ The UV-Vis spectrum of NT, recorded in a THF/ $\mathrm{H}_{2} \mathrm{O}$ (9:1) HEPES buffered solvent system $(\mathrm{pH}$ 7.4) is shown in Figure 1 and is characterised by a broad absorption from 210 to $450 \mathrm{~nm}$. Within this broad absorption profile there is evidence of four main peaks with $\lambda_{\max }$ values of $210,245,320$ and $370 \mathrm{~nm}$. The 210 and $245 \mathrm{~nm}$ peaks are consistent with $\pi-\pi^{*}$ transitions of the aromatic rings, the $320 \mathrm{~nm}$ peak with a $\pi-\pi^{*}$ transition of the $\mathrm{C}=\mathrm{N}$ group while the $370 \mathrm{~nm}$ band reflects an intramolecular charge transfer (CT) band of the entire conjugated molecule. ${ }^{11}$ When excited at $370 \mathrm{~nm}$ in the same solvent system the fluorescence spectrum exhibited two main bands in the visible region with $\lambda_{\max }$ values of 425 and $485 \mathrm{~nm}$ (Fig. 2a). The presence of two bands in the fluorescence spectrum enables the possibility
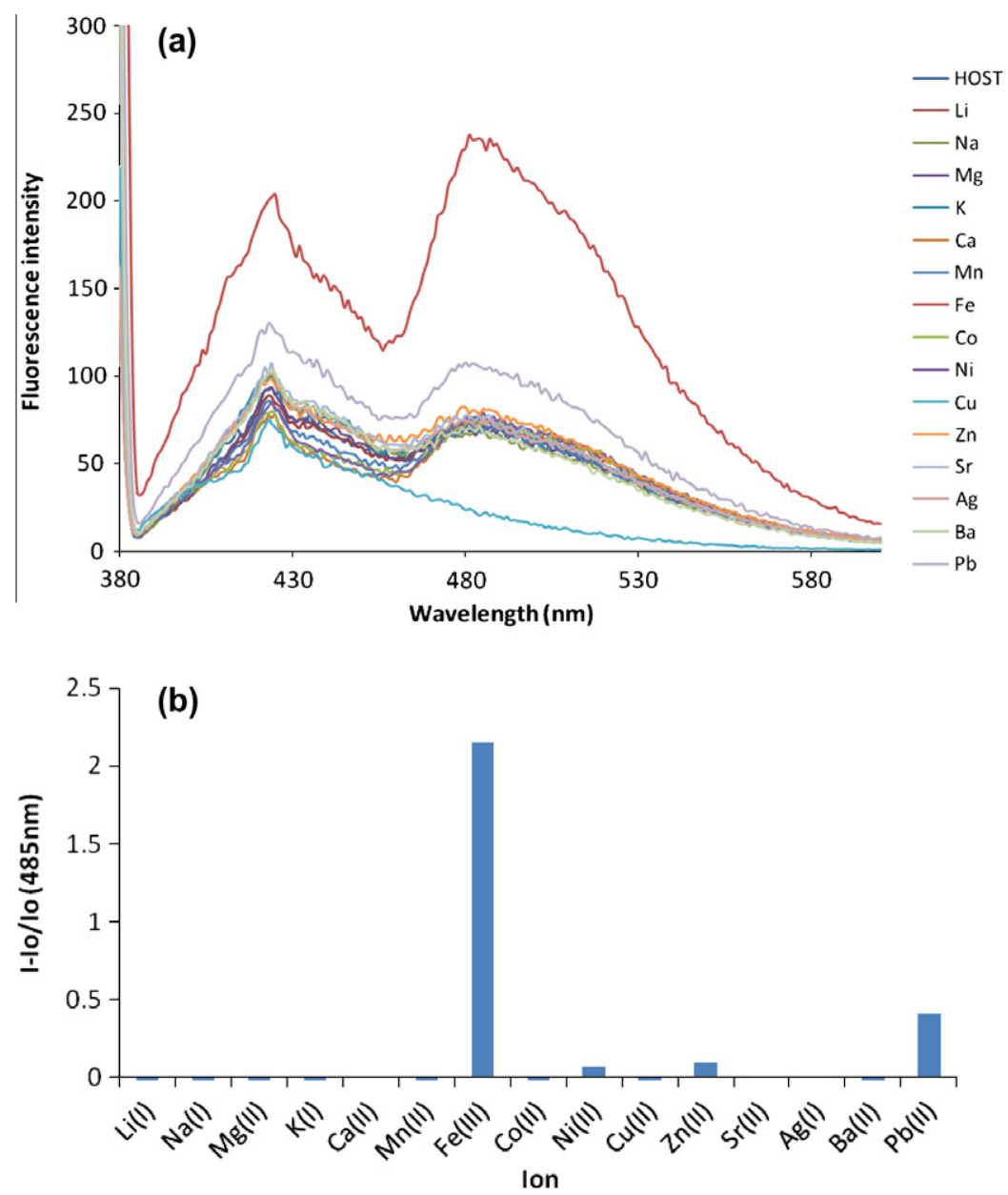

Figure 2. (a) Fluorescence spectra of $\mathbf{N T}(10 \mu \mathrm{M})$ in the absence and presence of different metal salts $(25 \mu \mathrm{M})$ recorded in a THF/ $\mathrm{H}_{2} \mathrm{O}(9: 1)$ solvent system buffered at pH 7.4 . Excitation wavelength $=375 \mathrm{~nm}$ (b) selectivity plot for NT where $I-I 0 / I 0$ is plotted against each metal ion ( $I$ is the intensity in the presence of metal ion and $I 0$ the intensity in the absence of metal ion). 


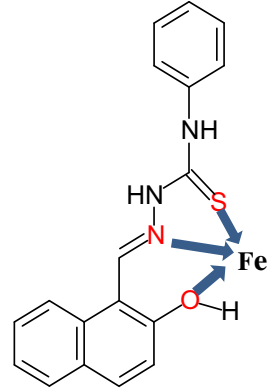

Figure 3. Proposed binding mechanism between $\mathbf{N T}$ and $\mathrm{Fe}^{3+}$.

of ratiometric analysis by comparing the ratio of the intensities of the two bands as a function of analyte concentration. This is preferred over single wavelength analysis as the method is free from the errors associated with receptor concentration, photobleaching and environmental effects. ${ }^{12}$

The selectivity of NT as a fluorescent probe for $\mathrm{Fe}^{3+}$ was tested in a $\mathrm{THF} / \mathrm{H}_{2} \mathrm{O}(9: 1)$ solvent system buffered at $\mathrm{pH} 7.4$ by incubating NT $(10 \mu \mathrm{M})$ with a range of environmentally and biologically important metal ions $(25 \mu \mathrm{M})$ as their chloride salts. The addition of $\mathrm{Li}^{+}, \mathrm{Na}^{+}, \mathrm{Mg}^{2+}, \mathrm{K}^{+}, \mathrm{Ca}^{2+}, \mathrm{Mn}^{2+}, \mathrm{Co}^{2+}, \mathrm{Ni}^{2+}, \mathrm{Zn}^{2+}, \mathrm{Sr}^{2+}, \mathrm{Ag}^{+}$and $\mathrm{Ba}^{2+}$ caused virtually no change to the fluorescence spectrum of NT. The addition of $\mathrm{Pb}^{2+}$ caused a minor increase in both bands while the addition of $\mathrm{Cu}^{2+}$ led to a slight increase of the $425 \mathrm{~nm}$ band with a significant quench of the $485 \mathrm{~nm}$ band (Fig. 2a). However, the addition of $\mathrm{Fe}^{3+}$ resulted in a significant increase of both bands with a $104 \%$ increase for the $425 \mathrm{~nm}$ band and a $194 \%$ increase for the $485 \mathrm{~nm}$ band. When a plot of the intensity at $485 \mathrm{~nm}$ was performed for each metal ion, excellent selectivity was observed for $\mathrm{Fe}^{3+}$ over all the other tested ions (Fig. 2b).

The reason for the large fluorescent enhancement upon the addition of iron can be explained as follows: iron is known to form a tridentate chelate with thiosemicarbazones such as NT (Fig. 3), where the oxygen lone pair from the naphthyl hydroxy, the imine nitrogen lone pair and the thiosemicarbazone sulfur lone pair, all bind strongly to the $\mathrm{Fe}^{3+}$ ion. ${ }^{13}$ This binding event prevents the rapid isomerisation of the $\mathrm{C}=\mathrm{N}$ group that otherwise happens in the absence of $\mathrm{Fe}(\mathrm{III})$ and which leads to non-radiative decay of the excited state. ${ }^{14}$ Examples of 'Off-On' fluorescence sensors for Fe(III) are rare given in the redox nature of this ion as it typically quenches the excited state of organic fluorophores by electron transfer processes when brought into close proximity of the fluorophore. ${ }^{15}$ In the case of NT, the enhancement in fluorescence that arises as a result of the inhibition of the $\mathrm{C}=\mathrm{N}$ isomerisation process is greater than the quenching ability of $\mathrm{Fe}^{3+}$ and an 'Off-On' response was observed.

To determine the sensitivity range over which NT can measure $\mathrm{Fe}(\mathrm{III})$, a series of solutions were prepared in which the concentration of NT was kept constant but the concentration of $\mathrm{Fe}^{3+}$ was gradually increased. The fluorescence of each solution was measured and the ratiometric intensity $\left(\mathrm{I}_{485} / \mathrm{I}_{425}\right)$ plotted against concentration (Fig. 4). Excellent linearity was observed in the $17-37 \mu \mathrm{M}$ range indicating that NT can function as a ratiometric 'Off-On' fluorescent sensor in this range. To confirm the binding stoichiometry between NT and $\mathrm{Fe}^{3+}$ a Job plot was performed. ${ }^{16}$ The results of this plot are shown in Figure 5 and indicate the formation of a 1:1 (host/guest) complex. Based on a 1:1 binding stoichiometry the binding constant $(\log \beta)$ was calculated to be 4.56 using the equation $\log \left(F_{\max }-F\right) /\left(F / F_{\min }\right)=\log [$ cation $]-\log \beta$, (where $F_{\max }$ is the maximum fluorescence intensity, $F_{\min }$ the minimum fluorescence intensity and $F$ the measured fluorescence intensity). ${ }^{17}$
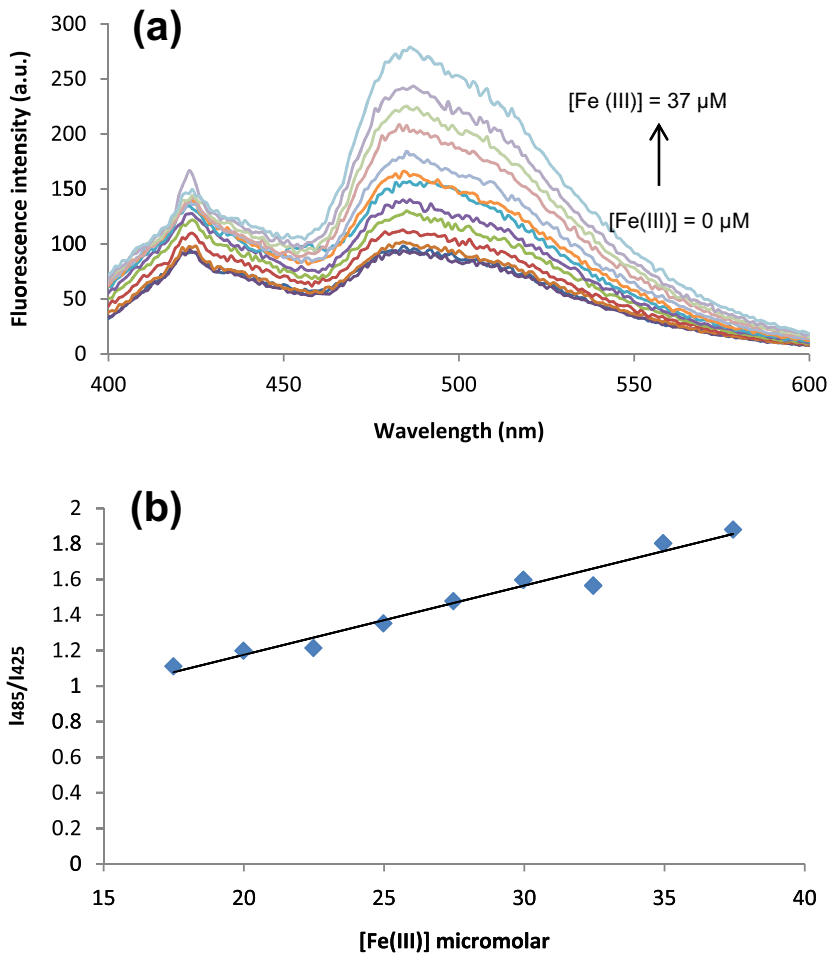

Figure 4. (a) The concentration dependent increase in fluorescence of NT upon increasing $\left[\mathrm{Fe}^{3+}\right]$. (b) Plot of the ratiometric fluorescence intensity of $\mathbf{N T}\left(\mathrm{I}_{485} / \mathrm{I}_{425}\right)$ against $\mathrm{Fe}^{3+}$ concentration. [NT] $=10 \mu \mathrm{M}$, solvent: $\mathrm{THF} / \mathrm{H}_{2} \mathrm{O}(9: 1)$ buffered at $\mathrm{pH}$ 7.4.

Finally, the effect of solution $\mathrm{pH}$ on the fluorescence intensity of NT was investigated by recording the fluorescence spectra over a range of different $\mathrm{pH}$ values. The emission intensity at $485 \mathrm{~nm}$ was plotted as a function of $\mathrm{pH}$ and this plot is shown in Figure 6 . These results illustrate that the fluorescence intensity remains relatively constant from $\mathrm{pH} 2-9$, but increases dramatically from $\mathrm{pH}$ $10-12$. This large increase in fluorescence is most likely caused by the deprotonation of the naphthalene hydroxy group of NT that otherwise leads to a non-radiative decay from the excited state by vibrationally coupling it to water. ${ }^{11}$ As this hydroxy group is also involved in the binding of the $\mathrm{Fe}^{3+}$ ion by NT, it is also probable that this interaction may also contribute to the fluorescence enhancement observed upon the interaction of $\mathbf{N T}$ and $\mathrm{Fe}^{3+}$, as this binding event would reduce the ability of the hydroxy group vibrationally coupling to water. The $\mathrm{p} K_{\mathrm{a}}$ of this group was calculated to

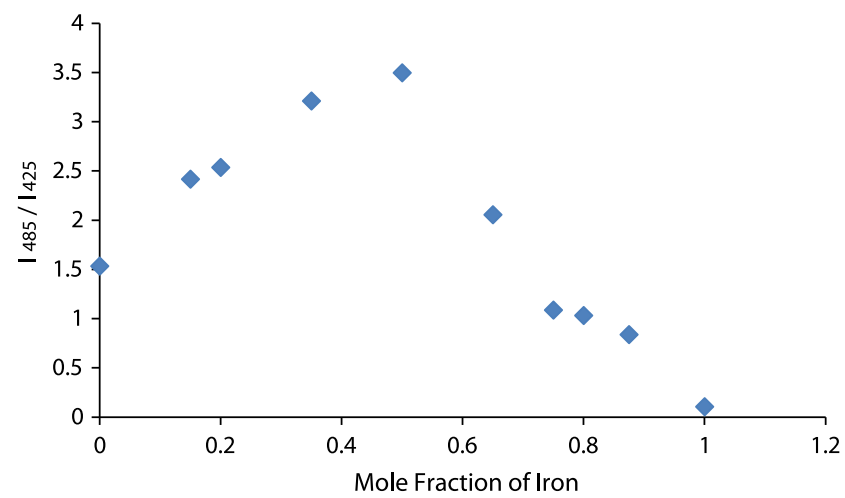

Figure 5. (a) Job plot for NT and $\mathrm{Fe}^{3+}$ illustrating the formation of a $1: 1\left(\mathbf{N T} / \mathrm{Fe}^{3+}\right)$ complex. 


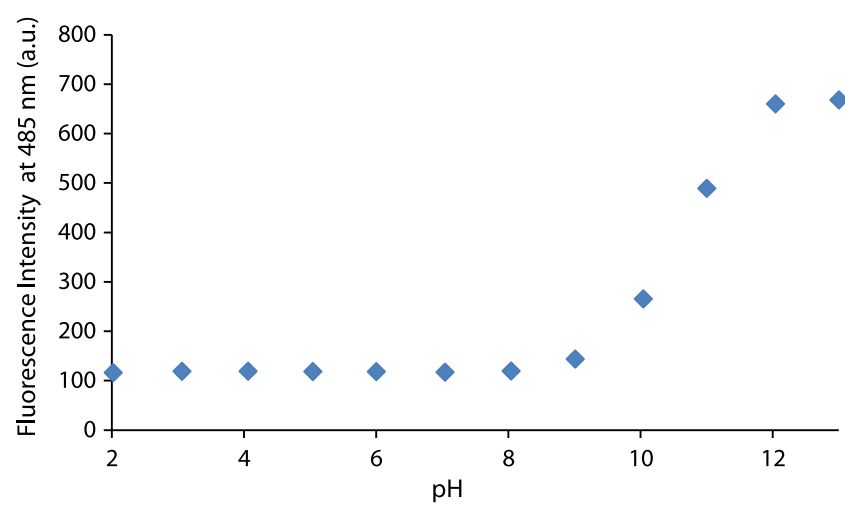

Figure 6. Plot of fluorescence against $\mathrm{pH}$ for NT. [NT] $=10 \mu \mathrm{M}$.

be 10.62 using a derivation of the Henderson Hasselbach equation by plotting $-\log \left(F_{\max }-F\right) /\left(F-F_{\min }\right)$ against $\mathrm{pH} .{ }^{18}$ Importantly, however, the fluorescence-pH titration showed that the emission intensity of NT remained constant in the physiological range.

In summary, we have utilised NT as an 'Off-On' ratiometric fluorescence sensor for $\mathrm{Fe}^{3+}$ operable in semi aqueous solution. This compound displayed good selectivity for $\mathrm{Fe}^{3+}$ when tested against a range of physiological and environmentally important ions and was sensitive in the $17-37 \mu \mathrm{M}$ range. The fluorescence enhancement upon binding $\mathrm{Fe}^{3+}$ was attributed to a cancellation of the $\mathrm{C}=\mathrm{N}$ isomerisation that otherwise leads to non-radiative decay of the excited state. The binding stoichiometry was confirmed as $1: 1\left(\mathbf{N T} / \mathrm{Fe}^{3+}\right)$ and the binding constant $\log \beta$ was determined as 4.56. Examples of enhancement based ratiometric fluorescence sensors for $\mathrm{Fe}^{3+}$ are extremely rare and to the best of our knowledge, $\mathbf{N T}$ is the first reported example of an enhancement based fluorescence probe for $\mathrm{Fe}^{3+}$ that operates via the suppression of $\mathrm{C}=\mathrm{N}$ isomerisation. In addition, we believe that this provides a good example of how already synthesised molecules can be utilised for a different purpose. We are currently investigating other known iron-chelating compounds for their potential as optical iron sensors.

\section{References and notes}

1. Hentze, M. W.; Muckenthaler, M. U.; Galy, B.; Camaschella, C. Cell 2010, 142, 24-38.

2. Lieu, P. T.; Heiskala, M.; Peterson, P. A.; Yang, Y. Mol. Aspects Med. 2001, 22, 1-

3. Kalinowski, D.; Richardson, D. Pharmacol. Rev. 2005, 57, 547-583.

4. Barnham, K.; Masters, C.; Bush, A. Nat. Rev. Drug Disc. 2004, 3, 205-214.

5. Green, D.; Antholine, W.; Wong, S.; Richardson, D.; Chitambar, C. Clin. Cancer Res. 2001, 7, 3574-3579.

6. British National Formulary; Royal Pharmaceutical Society of Great Britain, 2009.

7. Callan, J. F.; de Silva, A. P.; Magri, D. C. Tetrahedron 2005, 61, 8551-8588.

8. (a) Moore, E. C.; Booth, B. A.; Sartorel, A. C. Cancer Res. 1971, 31, 235; (b) Sartorel, A. C.; Agrawal, K. C.; Moore, E. C. Biochem. Pharmacol. 1971, 20, 3119; (c) Spingarn, N.; Sartorelli, A. Abstr. Pap. Am. Chem. Soc. 1978, 175, 64; (d) Finch, R.; Liu, M.; Grill, S.; Rose, W.; Loomis, R.; Vasquez, K.; Cheng, Y.; Sartorelli, A. Biochem. Pharmacol. 2000, 59, 983-989.

9. Lovejoy, D.; Richardson, D. Blood 2002, 100, 666-676.

10. UV and Fluorescence Spectroscopy: Absorbance measurements were recorded on a Varian Cary 50 Spectrometer using $10 \mathrm{~mm}$ quartz cuvettes. Fluorescence measurements were recorded on a Cary Eclipse fluorimeter using $10 \mathrm{~mm}$ quartz cuvettes. Excitation slit size was $5 \mathrm{~nm}$ and emission slit size was $5 \mathrm{~nm}$. Synthesis of NT: 2-hydroxy-1-naphthaldehyde ( $0.5 \mathrm{~g}, 2.9 \mathrm{mmol})$ was added to $\mathrm{N}$-phenylhydrazinecarbothioamide $(0.49 \mathrm{~g}, 2.9 \mathrm{mmol})$ in $\mathrm{DMF}(15 \mathrm{~mL})$ at room temperature. After stirring for $18 \mathrm{~h}$, the solvent was evaporated under reduced pressure and the crude product recrystallised from hot EtOH. The resulting yellow crystals were dried in vacuo to yield $0.61 \mathrm{~g}$ of $\mathbf{1}$ (65\% yield). ${ }^{1} \mathrm{H}$ NMR $\left(500 \mathrm{MHz}, \mathrm{DMSO}-d_{6}\right): 6.95(2 \mathrm{H}, \mathrm{m}, \mathrm{Ar}-\mathrm{H}), 7.14(3 \mathrm{H}, \mathrm{m}, \mathrm{Ar}-\mathrm{H}), 7.32(3 \mathrm{H}, \mathrm{m}, \mathrm{Ar}-$ $\mathrm{H}), 7.61(2 \mathrm{H}, \mathrm{m}, \mathrm{Ar}-\mathrm{H}), 8.23(1 \mathrm{H}, \mathrm{s}, \mathrm{Ar}-\mathrm{H}), 8.90(1 \mathrm{H}, \mathrm{s}, \mathrm{CH}=\mathrm{N}), 9.80(1 \mathrm{H}, \mathrm{s}, \mathrm{NH})$, $10.34(1 \mathrm{H}, \mathrm{s}, \mathrm{OH}), 11.50(1 \mathrm{H}, \mathrm{s}, \mathrm{NH}) .{ }^{13} \mathrm{C}$ NMR $(125 \mathrm{MHz}$ DMSO-d 6 ): 110.2 , $119.0,124.0,125.6,128.6,129.2,132.1,133.1,139.7,144.0,157.1 . \mathrm{MS}$ : Calculated for $\mathrm{C}_{18} \mathrm{H}_{15} \mathrm{~N}_{3} \mathrm{SO}=321.4$, found 321.1.

11. Issa, R. M.; Khedr, A. M.; Rizk, H. J. Chin. Chem. Soc. 2008, 55, 875-884.

12. Singh, N.; Kaur, N.; Mulrooney, R. C.; Callan, J. F. Tetrahedron Lett. 2008, 49, 6690-6692.

13. Antholine, W.; Knight, J.; Whelan, H.; Petering, D. Mol. Pharmacol. 1977, 13, 8998 .

14. Bhardwaj, V. K.; Pannu, A. P. S.; Singh, N.; Hundal, M. S.; Hundal, G. Tetrahedron 2008, 64, 5384-5391.

15. (a) Fabbrizzi, L.; Poggi, A. Chem. Soc. Rev. 1995, 24, 197-202; (b) Singh, N.; Mulrooney, R. C.; Kaur, N.; Callan, J. F. J. Fluoresc. 2009, 19, 777-782; (c) Singh, N.; Kaur, N.; Dunn, J.; MacKay, M.; Callan, J. F. Tetrahedron Lett. 2009, 50, 953956.

16. Espada-Bellido, E.; Dolores Galindo-Riano, M.; Garcia-Vargas, M.; Narayanaswamy, R. Appl. Spectrosc. 2010, 64, 727-732.

17. (a) De Silva, A.; Gunaratne, H.J. Chem. Soc., Chem. Commun. 1990, 186-188; (b) De Silva, A.; Gunaratne, H.; Lynch, P. J. Chem. Soc., Perkin Trans. 2 1995, 685-690.

18. Kamila, S.; Callan, J. F.; Mulrooney, R. C.; Middleton, M. Tetrahedron Lett. 2007, $48,7756-7760$. 